\title{
Determinants of the Venture Investment Size in Russian IT Companies
}

\section{Rodionov, Ivan I.}

Doctor of Sciences (Economics),

Department of Finances, National Research University Higher School of Economics, 20, Myasnitskaya st., Moscow, Russia

E-mail: irodiono@mail.ru

\section{Semenov, Alexander S.}

$\mathrm{PhD}$,

Department of Finances, National Research University Higher School of Economics, 20, Myasnitskaya st., Moscow, Russia

E-mail: semenov.venture@mail.ru

\section{Seleznev, Vladimir A.}

Capital Investment Analyst

VTB

12, Presnenskaya embankment, Moscow, Russia

E-mail: volodymyr.seleznov@gmail.com

\begin{abstract}
This study investigates the key determinants of the size of investment in Russian IT companies during follow-on rounds starting from the second round. On a sample of 55 deals (2010-2016), which represents the most important deals on Russian market, the research finds out two key factors positively influencing the size of investments: investments in the first round and presence of experienced investor among shareholders. The investor was considered as experienced if she has had success on VC market or has a totally accepted reputation on the same market. Results are consistent with the prior literature including the preliminary results of the authors done on lesser datasets. Additionally, effects of belonging to a particular industry or the time period of investments were proved to be insignificant for Russian VC market for IT companies. New hypothesis proposed by the authors (about impact of the number of founders on the investment in subsequent rounds) as well as hypothesis about the impact of target market growth on the investment size are also rejected. The latter is surprising as the target market growth is considered among the most important criteria for the investment decision. The result may be explained by the bias of the dataset as most of the early stage company data is confidential, and the target market growth plays the most significant role at the beginning of investment process.
\end{abstract}

Keywords: determinants, venture capital, microeconomic factors, macroeconomic factors, investment activity, rounds of investments

JEL: G24 
Venture capital is one of the most effective tools for supporting IT sector of the economy. Involving venture capital in order to raise the share of non-state financing sources for innovative projects is a necessary condition for increasing the competitiveness of the domestic economy. Moreover, it becomes one of the priority tasks for the state.

The work of many domestic and foreign researchers is devoted to the problems of choice of optimal mechanisms for selecting investment projects and the improvement of venture investments' efficiency. However, there is a problem of the absence of practical tools for determining the key factors of the activism of the venture investment market in Russia, which allow to forecast the most effective ways of development of the venture industry.

\section{Literature review}

Many investigators are interested in exploring venture capital investments and their determinants. Nevertheless, they study this issue on the foreign markets individually or do a cross-country analysis. Thus, Jeng and Wells (2000) considered determinants of venture capital for 21 countries, Bonini and Alkan (2006) investigated 16 countries and Schertler (2003) studied 14 European countries. Phenomenon of venture investments in IT companies in Russia is poorly studied, mostly because of lack of available information about deals. However, aggregated data on this issue are analyzed mainly by RusBase, CrunchBase, AngelList, EY, PwC, Russian Venture Company and some research centers. Basic empirical research on this issue was held in the works of Semenov and Gosteva (2014), Semenov and Sokolova (2015).

One of the internal factors that affects the volume of venture capital investments is the presence of experienced investor in the company's investors pool.

Semenov and Gosteva (2014) analyzed venture capital investments in Russian IT companies. They tried to identify main internal determinants of the volume of such investments in the second round. Moreover, this article was the first attempt to carry out an econometric study of the Russian venture market. Final sample consisted of more than 500 Russian IT-sector companies that have raised venture capital investments in the period from 2010 to 2014. It has been identified that the presence of experienced investors, which is understood as a major institutional investor, having experience of exit or long work experience in the Russian market, affects the size of the second round investments negatively. A possible explanation is that the experienced investors are prone to excessive frugality. However, it can be explained by the fact that experienced investors consider the optimal level of their investments lower than investors with less experience in the market, perhaps because the first one are confident that they will contribute to the growth of the company through their contacts and knowledge of the market. Besides, Semenov and Sokolova (2015) conducted the same analysis.
Firms that have raised venture capital investments usually operate in the market of IT services, mobile applications and acquiring, market of protection from leaks of confidential data. The initial information is supplemented with data on the forecasted growth of the market at the time of investment in the first round. It was assumed that investors in making their decisions are governed by market trends, and growth rates predicted by the leading agencies at the start of the investment, provide guidance for investors when making decisions. However, Semenov and Gosteva (2014), Semenova and Sokolova (2015) concluded that the growth of the market is not a significant variable.

On the basis of the model of Semenov and Gosteva (2014) it is possible to identify that there is a strong positive correlation of investments in the second round of the size of investment in the first round. It may be explained by the company's actions. On the other hand, it is possible that the presence of an investor in the previous round, regardless of the company's results, makes the company more attractive for investors. Furthermore, Semenov and Sokolova (2015) and Martí and Balboa (2001) on a sample of 16 European countries for 1987-1999 obtained similar results.

Although in the foreign literature the various factors fostering the increase in the efficiency of venture investments have been studied in sufficient details, the direct transfer of the experience of developed countries to the Russian market is incorrect because of the significant institutional and infrastructural differences. Despite the large number of theoretical works revealing the problems of evaluating the effectiveness of venture business, there is a lack of practical research that can offer a comprehensive approach to finding ways to increase the activity of the venture capital market in Russia.

Thus, further improvement of methodological approaches to the creation of an effective model for the development of venture capital industry is necessary, and therefore the key importance is the identification of macroeconomic and microeconomic factors that have a significant impact on the development of the Russian venture capital market.

\section{Data and sample construction}

This study was based on the following data:

- The size of funding in the first round.

- The size of funding in the follow-on round.

- Presence of experienced investor among the stakeholders of the startup.

- Respective market growth expectations.

- Number of founders in the startup.

- Year of the investments.

- Industry of operations.

It worth mentioning, that first 4 factors were already analyzed in previous researches [Semenov and Gosteva, 2014; Semenov and Sokolova, 2015], while the last 3 ones were proposed by the authors. We did not find any previous studies devoted to these 3 determinants of venture capital investments in Russian and international papers. 
Table 1. The descriptive statistics

\begin{tabular}{|c|c|c|c|c|c|}
\hline Variable & Obs & Mean & Std. Dev. & Min & $\operatorname{Max}$ \\
\hline inv1 & 55 & 15.37 & 44.98 & 0.01 & 300.00 \\
\hline inv2 & 55 & 60.43 & 197.78 & 0.01 & 1200.00 \\
\hline ln_inv1 & 55 & .3866937 & 2.420766 & -4.60517 & 5.703783 \\
\hline ln_inv2 & 55 & 1.615232 & 2.315797 & -4.199705 & 7.090077 \\
\hline growth & 55 & 0.43 & 0.36 & 0.09 & 2.00 \\
\hline founders & 55 & 2 & 1 & 1 & 6 \\
\hline exp_inv & 55 & 0.53 & 0.50 & 0.00 & 1.00 \\
\hline
\end{tabular}

Source: Authors' analysis.

Most of the determinants from the analyzed sample ware taken primarily from the following databases:

- RusBase.

- CrunchBase.

- AngelList.

Market growth forecasts were taken from such sources as BMI, CNews, J'son \& Partners Consulting as well as from publicly available expert opinions and statements of management.

The structure of the sample (by number of deals) is represented below.

\section{Figure 1.}

Sample breakdown by sectors

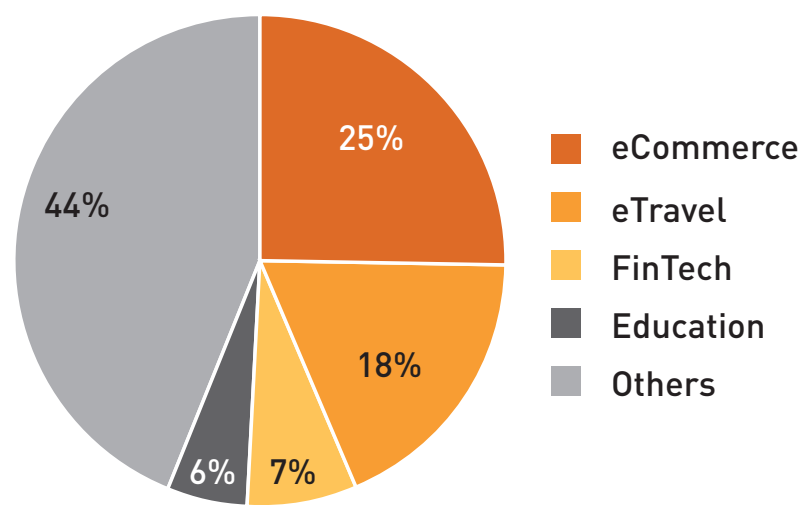

Source: Authors' analysis.

As we can see from the graph above, the largest groups are eCommerce (e.g. Lamoda, Wikimart, Ozon etc.) and eTravel (e.g. OneTwoTrip, Ostrovok, Bookinna, OnlineTours etc.).

Speaking about experienced investors, the sample is divided in the following order.
Figure 2. Sample breakdown by the presence of experienced investor

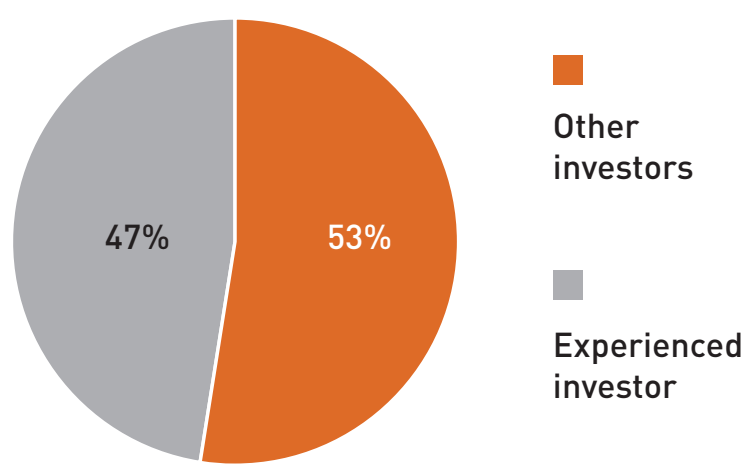

Source: Authors' analysis.

Experienced investors are represented by venture capital or private equity funds, which exited from their investments previously. They usually have respectable brand or international presence. Among such investors are Almaz Capital Partners, Fastlane Ventures, IFC, PPR, Intel Capital, European Bank for Reconstruction and Development, USM Advisors, Mail.ru Group, AB Kinnevik, Sequoia Capital, ru-Net Holdings, Tiger Global Management, Runa Capital, Da Vinci Capital, Vostok New Ventures, I2BF Global Venture, Internet Initiatives Development Fund and others.

Final sample consisted of 55 deals in Russian venture capital market from 2010 to 2016. This amount is explained by limited availability of data for all factors analyzed in this study. Information for the deals in this sample are most comprehensive and reliable.

\section{Variables description}

To investigate factors that influence the size of investments in Russian IT companies in follow-on rounds we decided to use OLS-model. 
As a result, the model has the following specification:

ln_inv $2=a+b 1 * \ln \_i n v 1+b 2 * \exp { }_{-} i n v+\ldots$

$\ldots+b 3 *$ growth $+b 4 *$ founders $+u$.

Dependent variable:

ln_inv2 - natural logarithm of the size of investments in follow-on rounds for Russian IT company in US dollars.

\section{Independent variables:}

ln_inv1 - natural logarithm of the size of investments in the first round for Russian IT company in US dollars;

exp_inv - dummy variable for the presence of experienced investor - takes 1 if a company has an experienced investor in the first round or 0 otherwise; growth - expected average growth of the specific sector of operations for the IT company (in percentage);

founders - the number of founders of the company.

The descriptive statistics of key variables is presented in the Table 1. All the hypotheses are tested via STATA. The results are presented below.

\section{Results}

The main model specification results showed that the size of investments in the first round and presence of experienced investor have a significant influence on the size of investments in follow-on rounds with $1 \%$ and $5 \%$ levels respectively, whereas expected market growth and number of founders have inconsiderable impact on the dependent variable. The results of the specification are represented in the table below.

Table 2. Main specification results

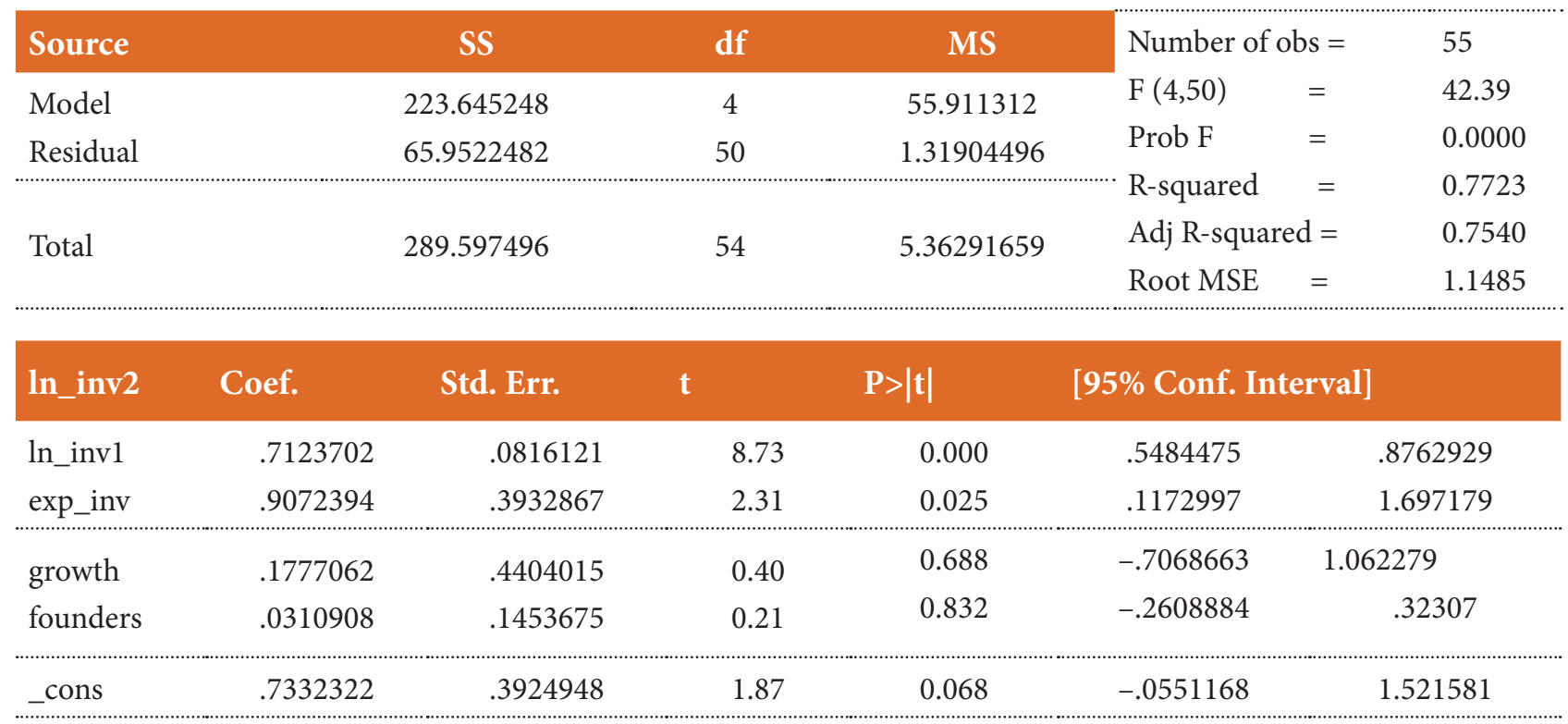

Source: Authors' analysis.

Investments in the first rounds and presence of experienced investor have positive effect on the size of investments in the follow-on rounds. Despite insignificance of the results, expected market growth and the number of founders also showed positive impact on the dependent variables. All the results (except for the numbers of founders) are consistent with the prior literature [Semenov and Gosteva, 2014; Semenov and Sokolova, 2015].

The first criteria for model is adjusted coefficient of determination that in comparison with ordinary $R^{2}$ takes into account the number of independent variables. The higher the $R_{a d j}{ }^{2}$ is the better model in terms of explained variance of the size of investments. As we can see from the table above that $R_{a d j}{ }^{2}$ equals $75 \%$, that shows high explanatory power of the model in general.

\section{Conclusion}

IT sector, as the object of investment, is one of the most popular and successful area for capital investment. IT companies in the modern world strengthen increasingly themselves in the market, and therefore, their attractiveness as a source of investment returns has arisen.

This work is purposed to determine impact of microeconomic and macroeconomic factors on the size of investments in Russian IT companies in the follow-on rounds of investments.

As all prior literature focuses mostly on developed countries analysis, this research adds considerable contribution to the finance discipline as it would provide specific view on the venture capital market in Russia. 
Based on literature review and authors' intuition, the model included four most well-grounded factors which were expected to show valid outcomes, and partially confirm the prior results of other researchers. According to the hypotheses, first round investments, presence of experienced investor, market growth forecast seem to be drivers for the size of investments in follow-on rounds, while the number of founders would decrease this dependent variable.

Overall, 2 of 6 hypotheses were confirmed on the whole sample. The strong significant impact of first round investments and presence of experienced investor was consistent with the results of prior studies such as Semenov and Gosteva (2014), Semenov and Sokolova (2015). It worth mentioning that in this study effects of belonging to particular industry or the time period of investments were proved to be insignificant. New hypothesis proposed by the authors (about impact of the number of founders) was also rejected.

To recapitulate, the size of investments in the follow-on rounds for Russian IT companies depends on the size of investments in the first round and presence of experienced investor. These determinants affect the size of funding in a positive way.

Potential reason for positive impact of the size of first round investments is that companies that have already raised substantial amount of funds are more interesting for new investors. These companies raised more funds and were valued higher in the initial stages, so they are likely to further grow in price in connection with the rapid growth of their business.

Impact of presence of experienced investor is based on willingness of potential investors to participate in the projects where their experienced colleagues have already taken some share. It is considered as a sign of quality of the startup as experienced investors usually do diligent analysis and check all potential risks for their investments. Additionally, experienced investors have a number of connections in the sector and may raise new investors to the project.

Overall, received results suggest also that specifics of Russian venture capital market include extremely strong reliance on relationships and access to sources of capital. These factors make much more impact on the size of investments in comparison with expected trends in the industry.

We expect this study to be useful for Russian venture capital investors and startup founders as well as guidance for further investigators of factors that influence the size of investments in IT companies.

\section{References}

Bertoni, F., Colombo Massimo, G., Quas A. (2017) The Role of Governmental Venture Capital in the Venture Capital Ecosystem: An Organizational Ecology Perspective. Entrepreneurship Theory and Practice, John Wiley \& Sons, Incorporated. URL: https://doi. org/10.1177/1042258717735303

Bonini, S., Alkan, S. (2006) The Macro and Political Determinants of Venture Capital Investments around the World. Working Paper, University of Bocconi.

Colombo Massimo, G., Murtinu, S. (2017) Venture Capital Investments in Europe and Portfolio Firms' Economic Performance: Independent Versus Corporate Investors. Journal of Economics \& Management Strategy, Vol. 26, Iss. 1, pp. 35-66. John Wiley \& Sons, Incorporated.

Jeng, L.A., Wells, Ph.C. (200) The determinants of venture capital funding: evidence across countries. Journal of Corporate Finance, Vol. 6(3), pp. 241-289.

Ivashkovskaya, I.V., Kokoreva, M.S., Makeeva, E.YU., Grigor'eva, S.A., Skvorcova, I.V., Stepanova, A.N., Kokorev, D.A. (2017) Strategicheskie finansovye resheniya kompanij na razvivayushchihsya rynkah kapitala. KNORUS. Kollektivnaya monografiya. Pod red. I.V. Ivashkovskoj.

Marti, J., Balboa, M. (2001) Determinants of private equity fundraising in Western Europe. EFMA. Lugano Meetings, 2001.

PwC i RVK "Money Tree: Navigator venchurnogo rynka. Obzor venchurnoj industrii Rossii za 2015 god”, 2015.

Schertler, A. (2003) Driving Forces of Venture Capital Investments in Europe: A Dynamic Panel Data Analysis, European Integration, Financial Systems and Corporate Performance (EIFC). Working paper, № 03-27, United Nations University.

Semenov, A., Gosteva, E. (2014) Major Determinants of the Volume of Venture Deals in the Russian IT Companies. Cloud of Science, Vol. 1, Iss. 2, pp. 337-348.

Semenov, A., Sokolova, O. (2015) Analysis of Determinants of Russian Private Equity and VC Industry Based on Data Sample. Cloud of Science, Vol. 2, Iss. 2, pp. 265-281.

Volkova, O. (2017) Otnosheniya s investorami (Investor Relations): mezhdunarodnyj kontekst, rossijskaya praktika. Korporativnye Finansy, 11(2), s. 81-95.

Volodin, S.N., Volkova, V.S. (2016) Rossijskij rynok venchurnyh investicij: aktual'nye problemy i puti ih resheniya. Korporativnye finansy, no. 2(38), s. 70-89. 


\section{Appendix}

List of the companies in the sample

- 2 can

- Amazing Hiring

- Avito

- Avtozaper

- B2B-Center

- Babadu

- BOOKINNA

- Buzzoola

- CarPrice

- Cinarra Systems

- Darenta

- Delivery Club
- Ecwid

- Eruditor Group

- Evernote

- Excursiopedia

- Fasten

- Fingooroo

- FreshOffice

- GridGain Systems

- IQcard.ru

- Ivi.ru

- KuponGid

- Lamoda
- $\quad$ My-Apps

- NGINX

- Oktogo

- OneTwoTrip

- Online Patent

- OnlineTours

- Ozon.ru

- REES46

- RoboCV

- RTB-Media

- Solomoto.ru

- TimePad
- Travelata

- Vitaportal

- Weatlas

- Wikimart

- Yaklass

- Будист

- Вконтакте

- Кнопка жизни

- КупиVIP

- Нетология

- Рокетбанк

- Яндекс 